\title{
Strategi Pengembangan Industri Wisata Era New Normal
}

\author{
Endra Yuafanedi Arifianto ${ }^{1}$, Susenohaji ${ }^{2}$, Dian Dinanti ${ }^{3}$, Dea Damaris ${ }^{4}$, \\ Dita Luxfianti ${ }^{5}$ \\ Jurusan Teknik Industri Universitas Brawijaya ${ }^{1,4,5}$, IImu Ekonomi Universitas \\ Brawijaya $^{2}$, Perencanaan Wilayah dan Kota Universitas Brawijaya ${ }^{3}$ \\ Email korespondensi : endra@ub.ac.id
}

\begin{abstract}
Abstrak : Aktivitas bisnis industri wisata Cafe Sawah Pujon Kidul mengalami penurunan pendapatan dengan adanya kebijakan Pembatasan Sosial Berskala Besar yang dilakukan pemerintah daerah Kota Batu. Perkembangan industri wisata di Kota Batu sangat mendukung peningkatan pendapatan desa. Khususnya industri wisata yang dikelola oleh masyarakat setempat melalui Badan Usaha Milik Desa (BUMDesa). Industri wisata mampu memberikan pertumbuhan ekonomi mikro masyarakat sekitar secara signifikan. Adanya pandemi covid 19 menjadi hambatan perkembangan usaha industri wisata. Untuk itu, penelitian ini bertujuan memberikan rekomendasi strategi pengembangan industri wisata di era new normal. Era kebiasaan dan tingkah laku masyarakat dengan memperhatikan protokol kesehatan dalam kehidupan sehari hari. Pengumpulan data dengan cara wawancara, diskusi, brainstorming dan pengisian kuisioner kepada responden. Metode penelitian ini menggunakan pendekatan analisis Internal Faktor Evaluation (IFE), External Faktor Evaluation (EFE) dan Bisnis Model Canvas dalam menyusun strategi pengembangan industri yang tepat di era new normal. Hasil Matrik Internal-Eksternal memiliki skor nilai 3,0;2,8 artinya berada di sel IV atau menggunakan strategi yang tumbuh dan membangun. Strategi tumbuh dan membangun dengan pendekatan penetrasi pasar dan pengembangan produk. Sedangkan BMC memberikan rekomendasi perbaikan sembilan elemen sesuai dengan kondisi di lapangan saat ini.
\end{abstract}

Kata kunci : Strategi, Industri Wisata, BMC, IFE, EFE

Pemberlakuan kebijakan pemerintah daerah tentang Pembatasan Sosial Berskala Besar (PSBB) dalam rangka memutus mata rantai pandemi Covid 19 memiliki dampak dalam penurunan omset industri wisata. Secara langsung industri wisata tidak beroperasi/beraktivitas, tidak boleh ada pengunjung atau di tutup. Kebijakan ini membuat semua masyarakat yang terlibat dalam aktivitas operasional bisnis tidak bekerja. Pengertian industri wisata menurut Undang - Undang Pariwisata no 10 tahun 2009 adalah kumpulan usaha pariwisata yang saling terkait dalam rangka menghasilkan barang dan/atau jasa bagi pemenuhan kebutuhan wisatawan dalam penyelenggaraan pariwisata. Industri wisata ada kegiatan proses produksi barang, pelayanan, transportasi, logistik, infrastruktur, kuliner, penginapan dan sebagainya. Sedangkan menurut Undang - Undang RI 2020 tentang UMKM mendefinisikan Usaha Mikro adalah usaha produktif milik orang perorangan dan/atau badan usaha perorangan yang memenuhi kriteria Usaha Mikro sebagaimana diatur dalam Undang-Undang ini. Keberadaan Industri Wisata ini mendorong masyarakat pelaku usaha mikro kecil dan menengah di sekitarnya ikut mengambil peran dengan menitipkan produk atau berjualan langsung disana. Aktivitas ini tentu memberikan alternatif pengenalan dan 
pemasaran produk - produk lokal masyarakat. Serangkaian aktivitas yang melibatkan banyak komponen penggerak ekonomi mikro khususnya masyarakat lokal sekitar lokasi wisata berhenti total saat penerapan Pembatasan Sosial Berskala Besar (PSBB). Kebijakan pemerintah daerah ini bersifat sementara sambil menunggu kondisi normal kembali seperti sedia kala sebelum pandemi terjadi. Waktu transisi ini biasa disebut era new normal dengan kata lain dikatakan era terjadi perubahan perilaku/kebiasaan masyarakat untuk melakukan aktivitas seperti biasa dengan mematuhi protokol kesehatan yang ketat. Perubahan kondisi saat ini tentu memiliki dampak sosial ekonomi di bidang industri wisata.

Salah satu industri wisata yang berkembang dengan pesat di Kabupaten Malang adalah Industri Wisata Cafe Sawah Pujon Kidul. Industri wisata ini dikelola oleh masyarakat yang terwadahi dalam Badan Usaha Milik Desa (BUMDesa). Data Pendapatan Asli Desa tahun 2018 sebesar Rp.1.883.000.000,- sebanyak 80 - 90 juta/bulan berasal dari Industri Wisata Cafe Sawah Pujon Kidul. Jumlah pendapatan yang sangat besar atau signifikan untuk skala desa. Pendapatan ini memberikan indikasi pertumbuhan ekonomi mikro masyarakat desa sekitar lokasi sedang mengalami pertumbuhan yang positif.

Kenyataan pertumbuhan ekonomi desa yang sangat signifikan akan mengalami penurunan bila di tutup selama beberapa bulan dengan berlakunya kebijakan pemerintah Pembatasan Sosial Berskala Besar (PSBB). Selain itu, setelah kebijakan itu berakhir di era transisi atau era new normal tentu juga akan mempengaruhi omzet Industri Wisata Cafe Sawah Pujon Kidul. Beberapa aktivitas bisnis yang di tawarkan di Industri Wisata Cafe Sawah Pujon Kidul diantaranya : ada kuliner khas Pujon Kidul yang ekonomis terjangkau dan enak, ada homestay untuk wisatawan yang ingin menginap dengan menikmati suasana pegunungan yang segar dan indah, edukasi pertanian di lahan pegunungan, edukasi peternakan dengan mengenal dan mengetahui cara berternak berbagai hewan peliharaan, aneka sayur hasil pertanian masyarakat sekitar yang diperjualbelikan dengan ekonomis, jasa travel/tour untuk menikmati dan mengantarkan wisatawan ke berbagai lokasi, berbagai produk olahan tangan/homemade souvenir masyarakat asli Pujon dan sebagainya. Semua aktivitas bisnis saling berkolaborasi dan bersinergi membangkitkan ekonomi mikro masyarakat menjadi satu kesatuan ekonomi Industri Wisata. Penelitian ini sangat penting dengan tujuan untuk mengetahui posisi bisnis industri wisata saat ini, kemudian menentukan strategi pengembangan untuk menghadapi era new normal dengan langkah langkah yang bisa diterapkan oleh semua komponen masyarakat. Khususnya pengelola dan pelaku UMKM yang tergantung dalam aktivitas bisnis industri wisata Cafe Sawah Pujon Kidul.

\section{METODE}

Obyek penelitian di Industri Wisata Cafe Sawah yang terletak di Desa Pujon Kidul, Kecamatan Pujon, Kabupaten Malang, Propinsi Jawa Timur. 
Pengumpulan data primer dengan menggunakan kuisioner terbuka dan tertutup melalui link google form kepada pelaku UMKM dan pengunjung yang sudah pernah berkunjung ke obyek penelitian. Kuisioner yang terkumpul di analisa dengan pendekatan Internal Faktor Evaluation (IFE), External Faktor Evaluation (EFE) dan Bisnis Model Canvas. Nilai skor dari analisa IFE dan EFE menunjukkan posisi obyek penelitian saat ini. Setelah diketahui matrik posisi bisnis obyek penelitian akan dilanjutkan menentukan rumusan strategi bisnis yang tepat di era new normal. Hasil kuisioner juga dapat digunakan untuk menyusun Bisnis Model Canvas saat ini sehingga mampu memberikan perbaikan proses bisnis di era new normal.

\section{HASIL}

\section{Analisis Internal Faktor Evaluation dan External Faktor Evaluation}

Internal Faktor Evaluation (IFE) digunakan untuk mengidentifikasi kekuatan dan kelemahan Industri Wisata Cafe Sawah Pujon Kidul. Hasil ini merupakan jawaban dari responden yang mengisi kuisioner dalam link google form penelitian.

Tabel 1. Matrik IFE

\begin{tabular}{|c|c|c|c|c|}
\hline No & Keterangan & Bobot & Rating & Skor \\
\hline \multicolumn{5}{|c|}{ Kekuatan } \\
\hline 1 & $\begin{array}{l}\text { Wisata memiliki keunggulan potensi kearifan lokal } \\
\text { dibandingkan dengan wisata lainnya }\end{array}$ & 0,08 & 3,17 & 0,25 \\
\hline 2 & $\begin{array}{l}\text { Tempat wisata sangat menarik dan memiliki } \\
\text { banyak spot untuk berfoto }\end{array}$ & 0,06 & 3,26 & 0,18 \\
\hline 3 & $\begin{array}{l}\text { Wahana bermain dalam tempat wisata beragam } \\
\text { jenisnya, aman dan nyaman untuk pengunjung }\end{array}$ & 0,04 & 2,71 & 0,10 \\
\hline 4 & $\begin{array}{l}\text { Wisata disini mampu memberikan kepuasan batin } \\
\text { pengunjung }\end{array}$ & 0,05 & 3,03 & 0,14 \\
\hline 5 & $\begin{array}{l}\text { Produk UMKM yang dijual menjadi ciri khas } \\
\text { produk unggulan masyarakat sekitar }\end{array}$ & 0,03 & 2,89 & 0,08 \\
\hline 6 & Produk UMKM yang dijual memiliki kualitas baik & 0,01 & 2,94 & 0,04 \\
\hline 7 & $\begin{array}{l}\text { Wahana disini selalu berkembang dan di tambah } \\
\text { jumlahnya }\end{array}$ & 0,03 & 2,89 & 0,07 \\
\hline 8 & Harga tiket masuk terjangkau & 0,06 & 3,20 & 0,22 \\
\hline 9 & $\begin{array}{l}\text { Harga tiket wisata bersaing dengan tempat } \\
\text { lainnya }\end{array}$ & 0,06 & 3,03 & 0,19 \\
\hline 10 & $\begin{array}{l}\text { Harga tiket masuk dinilai sesuai dengan kualitas } \\
\text { tempat wisata }\end{array}$ & 0,03 & 3,03 & 0,08 \\
\hline 11 & $\begin{array}{l}\text { Harga tiket masuk di waktu weekend lebih mahal } \\
\text { dibandingkan weekday }\end{array}$ & 0,03 & 2,53 & 0,07 \\
\hline 12 & Harga produk UMKM yang dijual terjangkau & 0,01 & 3,08 & 0,03 \\
\hline 13 & $\begin{array}{l}\text { Tempat wisata terdapat di lokasi yang strategis } \\
\text { dan mudah dicapai pengunjung }\end{array}$ & 0,06 & 2,74 & 0,15 \\
\hline 14 & $\begin{array}{l}\text { Jalan masuk ke tempat wisata dapat dengan } \\
\text { mudah dilewati oleh mobil }\end{array}$ & 0,03 & 2,80 & 0,08 \\
\hline 15 & $\begin{array}{l}\text { Tempat wisata terdapat di lokasi yang padat } \\
\text { penduduk }\end{array}$ & 0,01 & 2,74 & 0,04 \\
\hline 16 & Tempat wisata memudahkan jalur distribusi & 0,01 & 2,94 & 0,04 \\
\hline
\end{tabular}


produk UMKM ke pengunjung

17 Promosi tempat wisata dilakukan dengan cara $0,03 \quad 2,69 \quad 0,09$ mengikuti pameran

18 Promosi tempat wisata dilakukan secara word of

0,02

$3,00 \quad 0,05$

mouth

19 Promosi tempat wisata dilakukan melalui media sosial

20 Terdapat peta lokasi yang dapat memudahkan pengunjung untuk memahami area wisata

21 Terdapat sistem informasi untuk memudahkan proses bisnis

22 Data perusahaan tersimpan dengan baik dalam aplikasi database

23 Penjual produk UMKM sangat ramah dan pandai memasarkan produknya

24 Pekerja mengerti secara mendetail mengenai tempat wisata dan produk UMKM

25 Pekerja terampil dalam mengerjakan pekerjaannya

26 Pekerja melayani pengunjung dengan baik

27 Pekerja mayoritas berusia 20-30 tahun

28 Katalog tempat wisata dan produk UMKM memiliki tampilan yang menarik

29 Terdapat papan nama tempat wisata di pintu masuk

30 Memiliki legalitas usaha yang jelas

$0,01 \quad 2,97 \quad 0,02$

$0,01 \quad 2,91 \quad 0,03$

$0,01 \quad 2,74 \quad 0,02$

$0,01 \quad 2,66 \quad 0,02$

$0,00 \quad 2,97 \quad 0,01$

$0,01 \quad 2,89 \quad 0,02$

$0,01 \quad 2,89 \quad 0,02$

$0,01 \quad 2,91 \quad 0,04$

$0,01 \quad 2,69 \quad 0,03$

$0,00 \quad 2,83 \quad 0,01$

31 Memiliki reputasi yang baik di masyarakat

\section{Kelemahan}

$1 \quad$ Produk UMKM yang dijual kurang bervariasi

2 Harga tiket masuk belum termasuk semua wahana bermain yang ada di tempat wisata 3 Tidak terdapat potongan harga tiket masuk

4 Tempat wisata memiliki parkiran mobil dan motor yang kurang luas

5 Tempat wisata tidak selalu menjadi pusat pengembangan produk lokal / desa

6 Tempat wisata tidak selalu menjadi pusat pemasaran UMKM local

7 Tidak ada potongan harga tiket masuk yang diberikan untuk pembelian tiket dengan jumlah banyak

8 Belum ada promosi tempat wisata yang dilakukan oleh selebgram

9 Promosi tempat wisata tidak dibarengi dengan promosi produk UMKM

$0,01 \quad 2,94 \quad 0,03$

$0,01 \quad 2,94 \quad 0,03$

$0,01 \quad 3,11 \quad 0,04$

$0,04 \quad 3,11 \quad 0,12$

$0,04 \quad 2,97 \quad 0,13$

$0,02 \quad 2,80 \quad 0,08$

$0,02 \quad 3,17 \quad 0,07$

$0,04 \quad 3,03 \quad 0,14$

$0,01 \quad 3,03 \quad 0,06$

$0,02 \quad 2,57 \quad 0,06$

$0,01 \quad 2,57 \quad 0,03$

$0,01 \quad 2,86 \quad 0,03$

10 Promosi tempat wisata tidak berkaitan erat $0,01 \quad 2,80 \quad 0,02$ dengan promosi produk UMKM

11 Proses pemesanan tiket belum dapat dilakukan dengan berbagai cara

$0,02 \quad 2,60 \quad 0,04$ 


\begin{tabular}{rllll}
\hline 12 & $\begin{array}{l}\text { Proses pembayaran tiket masuk belum dapat } \\
\text { dilakukan dengan berbagai cara } \\
13\end{array}$ & 0,01 & 2,37 & 0,02 \\
$\begin{array}{l}\text { Manajemen belum mengedukasi pengunjung } \\
\text { dengan baik terkait produk UMKM local }\end{array}$ & 0,01 & 2,74 & 0,05 \\
14 & $\begin{array}{l}\text { Pekerja kurang paham mengenai sistem } \\
\text { informasi yang digunakan }\end{array}$ & 0,02 & 2,74 & 0,05 \\
15 & $\begin{array}{l}\text { Proses pengenalan potensi wisata dan produk } \\
\text { UMKM berjalan terpisah }\end{array}$ & 0,01 & 2,91 & 0,02 \\
16 & $\begin{array}{l}\text { Belum memiliki website ataupun media sosial } \\
\text { resmi milik perusahaan }\end{array}$ & 0,01 & 2,77 & 0,04 \\
17 & $\begin{array}{l}\text { Tidak semua industri wisata menyatu dengan } \\
\text { produk UMKM local }\end{array}$ & 0,01 & 2,91 & 0,02 \\
\hline & 1,00 & & 3,00 \\
\hline
\end{tabular}

Dengan skor bobot total sebesar 3,00 menunjukkan bahwa kondisi internal Industri Wisata Cafe Sawah Pujon Kidul memiliki kondisi yang kuat

External Faktor Evaluation (EFE) digunakan untuk mengidentifikasi peluang dan ancaman dari Industri Wisata Cafe Sawah Pujon Kidul.

Tabel 2. Matrik EFE

\begin{tabular}{lllll}
\hline No & \multicolumn{1}{c}{ Keterangan } & Bobot & Rating & Skor \\
\hline Peluang & & & \\
\hline 1 & $\begin{array}{l}\text { Pemerintah mendukung terhadap perkembangan } \\
\text { produk UMKM yang ada di wisata tersebut }\end{array}$ & 0,02 & 3,06 & 0,05 \\
2 & $\begin{array}{l}\text { Keadaan ekonomi masyarakat yang membaik } \\
\text { meningkatkan kunjungan ke tempat wisata }\end{array}$ & 0,02 & 2,91 & 0,05 \\
3 & $\begin{array}{l}\text { Daya beli masyarakat terhadap produk UMKM } \\
\text { meningkat }\end{array}$ & 0,05 & 2,89 & 0,13 \\
4 & $\begin{array}{l}\text { Meningkatnya minat dari masyarakat dalam } \\
\text { mengunjungi tempat wisata }\end{array}$ & 0,09 & 2,97 & 0,26 \\
5 & $\begin{array}{l}\text { Meningkatnya minat dari masyarakat dalam } \\
\text { membeli produk UMKM }\end{array}$ & 0,03 & 2,89 & 0,08 \\
6 & $\begin{array}{l}\text { Pengguna internet di Indonesia yang semakin } \\
\text { meningkat dari tahun ke tahunnya }\end{array}$ & 0,11 & 3,00 & 0,32 \\
7 & $\begin{array}{l}\text { Era Industri 4.0 dapat meningkatkan kualitas } \\
\text { proses bisnis dalam industri wisata }\end{array}$ & 0,03 & 3,03 & 0,09 \\
8 & $\begin{array}{l}\text { Peran teknologi mempermudah pengunjung } \\
\text { mengenali wisata baru dan produk UMKMnya }\end{array}$ & 0,13 & 2,97 & 0,37 \\
9 & $\begin{array}{l}\text { Kompetitor baru sulit untuk memasuki pasar } \\
\text { industri wisata }\end{array}$ & 0,03 & 2,49 & 0,07 \\
10 & $\begin{array}{l}\text { Kompetitor baru sulit untuk menguasai pasar } \\
\text { industri wisata }\end{array}$ & 0,02 & 2,40 & 0,05 \\
11 & $\begin{array}{l}\text { Produk ternama sulit untuk menguasai pasar yang } \\
\text { terdiri dari produk UMKM }\end{array}$ & 0,02 & 2,60 & 0,05 \\
12 & $\begin{array}{l}\text { Kompetitor produk menawarkan harga tiket yang } \\
\text { lebih mahal }\end{array}$ & 0,06 & 2,37 & 0,15 \\
13 & $\begin{array}{l}\text { Pemasok bahan baku berjumlah banyak } \\
\text { Pemasok bahan baku menawarkan kualitas yang } \\
\text { bervariasi }\end{array}$ & 0,01 & 2,69 & 0,03 \\
\hline
\end{tabular}


15 Pemasok menawarkan harga yang bervariasi

16 Pemasok produk UMKM berjumlah banyak

17 Pemasok produk UMKM memiliki mutu yang

0,01

2,86

0,01

2,80

0,04

bervariasi

18 Pemasok produk UMKM menawarkan harga yang bervariasi

19 Konsumen menginginkan kualitas tempat wisata yang baik

20 Konsumen menginginkan harga tiket masuk yang murah

21 Konsumen lebih memilih tempat wisata dengan reputasi yang baik

22 Konsumen mempertimbangkan kualitas produk UMKM yang dijual

\begin{tabular}{lllll}
\hline Ancaman & & & \\
\hline 1 & $\begin{array}{l}\text { Kompetitor baru menawarkan harga tiket yang } \\
\text { lebih murah }\end{array}$ & 0,02 & 2,71 & 0,04 \\
2 & $\begin{array}{l}\text { Kompetitor produk memiliki wahana bermain yang } \\
\text { lebih baik }\end{array}$ & 0,03 & 2,71 & 0,08 \\
3 & $\begin{array}{l}\text { Kompetitor UMKM sejenis menawarkan produk } \\
\text { yang lebih murah }\end{array}$ & 0,03 & 2,66 & 0,07 \\
4 & $\begin{array}{l}\text { Kompetitor UMKM sejenis menawarkan produk } \\
\text { yang kualitasnya lebih baik }\end{array}$ & 0,01 & 2,69 & 0,04 \\
5 & $\begin{array}{l}\text { Produk substitusi memiliki harga tiket masuk yang } \\
\text { lebih murah }\end{array}$ & 0,03 & 2,71 & 0,09 \\
6 & $\begin{array}{l}\text { Produk substitusi memiliki variasi wahana yang } \\
\text { lebih menarik }\end{array}$ & 0,02 & 2,80 & 0,04 \\
7 & $\begin{array}{l}\text { Produk substitusi memiliki kondisi yang lebih } \\
\text { nyaman }\end{array}$ & 0,01 & 2,80 & 0,04 \\
8 & $\begin{array}{l}\text { Produk substitusi UMKM memiliki harga yang } \\
\text { lebih rendah }\end{array}$ & 0,02 & 2,69 & 0,03 \\
9 & $\begin{array}{l}\text { Konsumen menginginkan adanya promo } \\
10\end{array}$ & $\begin{array}{l}\text { Konsumen mempertimbangkan fasilitas yang } \\
\text { ditawarkan ketika membeli tiket masuk }\end{array}$ & 0,02 & 3,03 \\
11 & $\begin{array}{l}\text { Konsumen mempertimbangkan harga produk } \\
\text { UMKM yang dijual }\end{array}$ & 0,04 & 0,05 \\
\hline
\end{tabular}

Nilai skor yang didapatkan oleh industri wisata berada di atas 2,8 namun masih jauh dari skor tertinggi yaitu 4,0 yang artinya masih banyak kesempatan yang dapat dimanfaatkan oleh industri wisata dengan lebih baik lagi.

Analisis Bisnis Model Canvas

Ada sembilan elemen yang saat ini terjadi dalam Industri Wisata Cafe Sawah Pujon Kidul, diantaranya :

1. Customer Segments, pelanggan industri wisata adalah masyarakat malang raya pada khususnya yang menyukai konsep wisata alam, pertanian, petualang, edukasi. Selain itu masyarakat Jawa Timur dan Indonesia pada umumnya. Semua usia sangat cocok dengan konsep 
yang ditawarkan, semua kalangan masyarakat ekonomi juga bisa mengakses.

2. Value Propositions, nilai yang membedakan industri wisata ini dibandingkan yang lainnya : berada di lahan pertanian produktif sehingga banyak hasil panen yang bisa dinikmati wisatawan, masakan dan produk khas asli masyarakat Desa Pujon Kidul, edukasi pertanian dan peternakan yang menarik, suasana lingkungan alami pegunungan yang sejuk, pemandangan alam yang indah, udara bersih dan segar. Kearifan lokal menjadi kekuatan bisnis industri wisata saat ini.

3. Channels, sarana untuk menyampaikan nilai atau manfaat dari produk jasa industri wisata dapat dijelaskan oleh Customer Service, Website, E-mail, Pelaku UMKM, pengelola BUM Desa. Elemen yang kurang optimal ditengah perkembangan teknologi yang sangat cepat saat ini.

4. Customer Relationships, menjalin hubungan yang baik dengan pelanggan menjadi kunci dari elemen ini. Saat ini belum ada startegi khusus dalam mengembangkan elemen Customer Relationships sehingga perlu ide kreatif dan terobosan program baru yang sesuai.

5. Revenue Streams, pembagian keuntungan yang terjadi harus di atur dengan baik, tertulis dan tersistem. Kolaborasi banyak elemen masyarakat ekonomi mikro memerlukan keputusan bersama dan saling menguntungkan. Penjualan produk dan jasa pelaku UMKM, homestay, pemilik lahan pertanian, kendaraan transportasi dan sebagainya belum terdatabase kan dengan sangat baik.

6. Key Resources, tersedianya sumber daya manusia masyarakat desa pujon Kidul, pelaku UMKM, Iahan pertanian produktif, peternak sekitar. Hal ini menjadi elemen dasar yang menjadi potensi yang harus dikelola dengan baik. Dengan semangat tumbuh bersama dan rasa memiliki akan sangat berpengaruh pada kesuksesan bisnis ini.

7. Key Activities, pemasaran (offline/online), produk kuliner, produk hasil pertanian, layanan edukasi dan penginapan. Menjadi kunci kesuksesan elemen ini terletak pada kolaborasi menghasilkan produk serta jasa yang memuaskan dan terbaik untuk seluruh konsumen/pengunjung.

8. Key Partnerships, pemerintahan Desa Pujon Kidul, direktur BUMDesa, pekerja, pelaku UMKM. Elemen ini menjadi indikator kesuksesan dengan menjalin kerjasama, sinergi dan hubungan yang baik dengan seluruh stekeholder terkait.

9. Cost Structure, Gaji tenaga kerja, biaya perawatan, biaya listrik, biaya operasional bulanan harus direncanakan dengan baik dan terkontrol sehingga mampu mempertahankan keuntungan. Evaluasi secara bertahap dan rutin bisa mengeliminasi pemborosan biaya sehingga mampu berhemat di tengah kondisi sulit saat ini. 


\begin{tabular}{|c|c|c|c|c|c|}
\hline \multirow[t]{2}{*}{$\begin{array}{l}\text { Key Partners } \\
\text { Pemerintahan } \\
\text { Desa } \\
\text { Direktur } \\
\text { BUMDes dan } \\
\text { Direktur Café } \\
\text { Sawah } \\
\text { Pekerja dan } \\
\text { pelaku UMKM }\end{array}$} & $\begin{array}{l}\text { Key } \\
\text { Activities } \\
\text { Pemasaran } \\
\text { (offline/online) } \\
\text { Layanan } \\
\text { Edukasi dan } \\
\text { penginapan }\end{array}$ & \multirow{2}{*}{\multicolumn{2}{|c|}{$\begin{array}{l}\text { Value } \\
\text { Propositions } \\
\text { lahan, } \\
\text { masakan dan } \\
\text { produk khas } \\
\text { asli } \\
\text { masyarakat } \\
\text { Desa Pujon }\end{array}$}} & $\begin{array}{l}\text { Customer } \\
\text { Relationships } \\
\text { Hubungan } \\
\text { yang baik }\end{array}$ & \multirow[t]{2}{*}{$\begin{array}{l}\text { Customer } \\
\text { Segments } \\
\\
\text { Masyarakat } \\
\text { Malang } \\
\text { Raya, Jawa } \\
\text { Timur dan } \\
\text { Masyarakat } \\
\text { Indonesia }\end{array}$} \\
\hline & $\begin{array}{l}\text { Key } \\
\text { Resources } \\
\text { SDM } \\
\text { masyarakat, } \\
\text { SDM pelaku } \\
\text { UMKM, } \\
\text { Lahan } \\
\text { pertanian }\end{array}$ & & & $\begin{array}{l}\text { Channels } \\
\text { Customer } \\
\text { Service } \\
\text { E-mail } \\
\text { Pelaku UMKM }\end{array}$ & \\
\hline \multicolumn{3}{|c|}{$\begin{array}{l}\text { Cost Structure } \\
\text { Gaji tenaga kerja, biaya perawatan, } \\
\text { biaya listrik, biaya operasional bulanan }\end{array}$} & \multicolumn{3}{|c|}{ ue Str } \\
\hline
\end{tabular}

\section{Gambar 1. Bisnis Model Canvas Saat ini}

\section{PEMBAHASAN}

Matriks Internal-Eksternal dibuat berdasarkan dua faktor kunci yaitu skor tertimbang matriks IFE dan skor tertimbang matriks EFE. Matriks IE diperlukan untuk mengetahui posisi industri wisata dan UMKM. Menurut David (2009), Matriks IE terbagi menjadi tiga bagian besar dengan implikasi strategi yang berbeda dalam setiap bagian. Setelah pengolahan data dilakukan, skor nilai tertimbang yang didapatkan Industri Wisata Cafe Sawah Pujon Kidul untuk matriks IFE adalah 3,00 dan skor nilai tertimbang untuk matriks EFE adalah 2,8. Total skor tertimbang IFE akan menjadi sumbu $x$ pada matriks IE dan skor tertimbang EFE akan menjadi sumbu y pada matriks IE. Sumbu $x$ dan sumbu y berfungsi untuk menentukan koordinat pada matriks IE. Koordinat Industri Wisata Cafe Sawah Pujon Kidul untuk matriks IE ini adalah $(3,0 ; 2,8)$. 


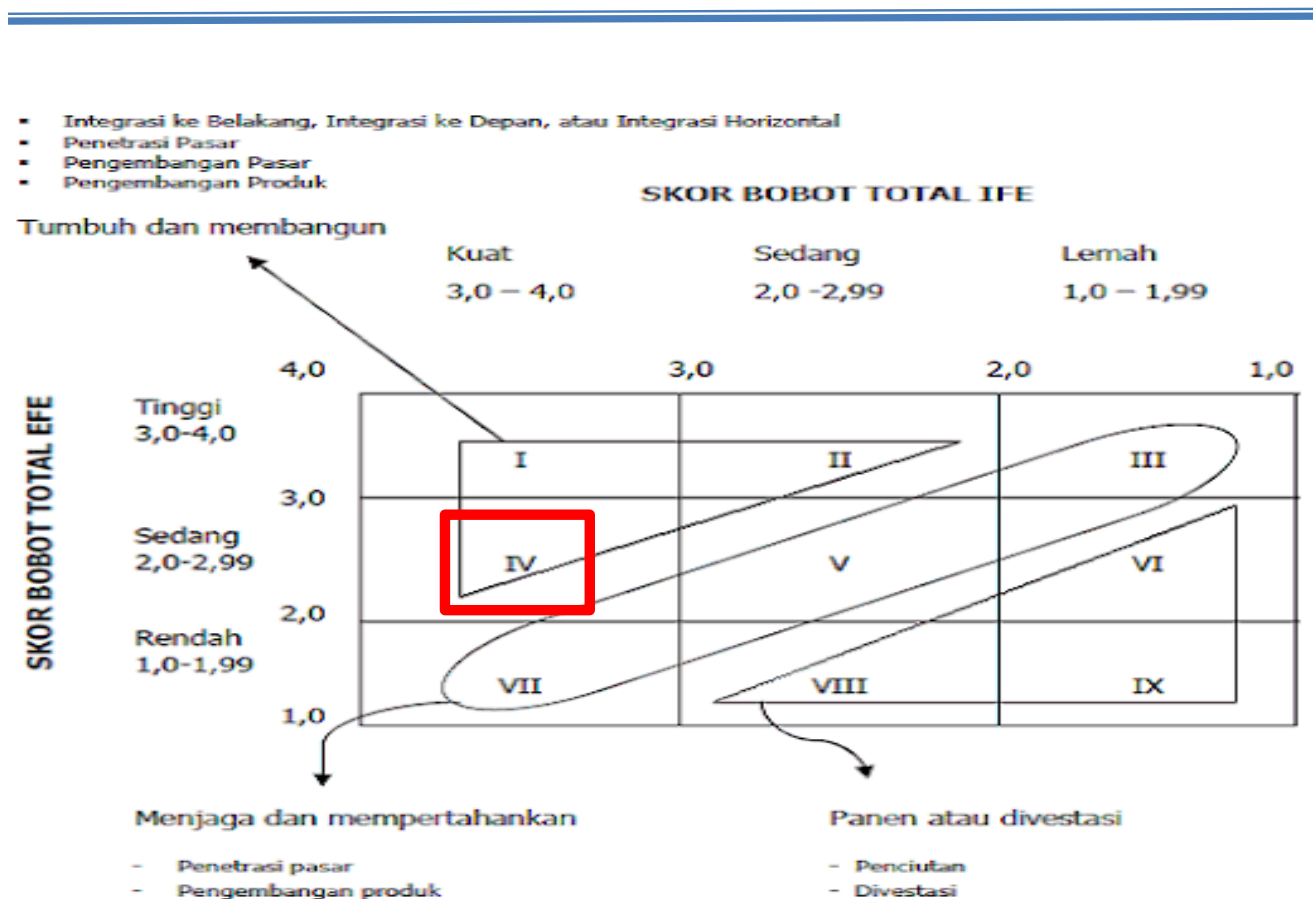

Gambar 2 Posisi Industri Wisata Cafe Sawah Pujon Kidul dalam Matriks IE

Sumber : Data yang diolah (2020)

Berdasarkan gambar 1 dapat dilihat bahwa Industri Wisata terletak pada sel IV. Pada sel I, II, dan IV dapat dikelola dengan baik menggunakan strategi yang tumbuh dan membangun, dalam bagian ini strategi yang banyak digunakan adalah dengan melakukan penetrasi pasar dan pengembangan produk. Penetrasi pasar berarti melakukan usaha untuk meningkatkan pemasaran dari Industri Wisata yang ditawarkan dengan lingkup usaha pemasaran yang lebih besar. Sedangkan pengembangan produk berarti sebuah unit bisnis memperkenalkan produk baru ke pasar yang telah ada. Strategi ini digunakan untuk mencari kenaikan penjualan dengan melakukan suatu inovasi atau modifikasi terhadap Industri Wisata maupun produk UMKM yang ditawarkan.

Strategi IE pertama yang dapat dilakukan adalah dengan melakukan promosi melalui media digital/media sosial serta melakukan kolaborasi bersama dengan lembaga/komunitas potensial seperti selebgram atau influencer. Hal ini dapat dijadikan peluang untuk memperkenalkan Industri Wisata Pujon Kidul di kalangan masyarakat luas dengan melihat dari penggunaan smartphone yang sangat tinggi serta pengguna media sosial yang semakin meningkat. Hal yang perlu diperhatikan dalam kegiatan promosi melalui media sosial adalah konten dan pembawaan yang menarik. Dengan adanya media sosial sebagai wadah untuk mempromosikan akan membuat konsumen lebih mengenal Industri Wisata Cafe Sawah Pujon Kidul bersama produk UMKM di Malang. Selain itu optimalisasi semua media official yang sudah ada perlu dilakukan oleh tenaga ahli atau bagian khusus yang memiiki sumber daya manusia yang tepat. Perlu perencanaan dan pelaksanaan yang matang dalam meningkatkan sumber daya manusia yang sudah ada untuk di latih lebih 
serius supaya memiliki skill yang memadai khususnya dalam melakukan interaksi dengan konsumen, menjelaskan produk barang dan jasa yang ditawarkan oleh Industri Wisata, kemampuan mempengaruhi masyarakat dan kemampuan menggunakan teknologi informasi/sosial media. Hal ini dapat dilakukan dengan kerjasama dan kolaborasi dengan lembaga pendidikan perguruan tinggi dan perusahaan yang profesional. Promosi era new normal ditekankan pada kesiapan industri wisata dalam menjamin pengunjung dengan protokol kesehatan (menyediakan masker, tempat cuci tangan, ruang kesehatan dan sebagainya).

Strategi IE selanjutnya adalah dengan melakukan survey lapangan ke Industri Wisata sejenis di dalam atau diluar negeri karena hal ini dapat membuka wawasan serta dapat memunculkan ide-ide baru bagi stakeholder untuk melakukan pengembangan terhadap industri wisata dan UMKM baik dari segi pengembangan proses bisnis dan sebagainya yang telah ditetapkan. Semakin banyak ilmu yang didapatkan dan diterapkan maka inovasi yang terjadi di industri wisata dan UMKM akan semakin banyak. Dengan adanya inovasi baru maka dapat menambah daya tarik konsumen atau pengunjung untuk mengunjungi industri wisata dan UMKM. Strategi ini perlu di dukung dengan memunculkan bidang khusus tentang pengembangan produk industri wisata yang terdiri dari pengelola, lembaga pendidikan, perusahaan profesional dan komunitas.

Terobosan baru yang perlu diterapkan untuk perbaikan dan peningkatan kualitas bisnis Industri Wisata dengan melakukan tindakan, diantaranya :

1. Customer Segments, masih tetap menggunakan yang awal

2. Value Propositions, penambahan fasilitas kesehatan yang siap memberikan layanan di lokasi industri wisata dengan berkolaborasi dengan dinas terkait dan lembaga perguruan tinggi. Penerapan protokol kesehatan sesuai pedoman dinas kesehatan mendukung keberlangsungan bisnis di masa era new normal. Dengan adanya jaminan keamanan dan kesehatan dengan protokol Covid 19 diharapkan membuat pengunjung nyaman dan merasa aman saat berkunjung ke Industri Wisata.

3. Channels, melakukan kerjasama dan kolaborasi dalam mengoptimalkan media official partner sebagai sarana untuk mengenalkan setiap produk barang dan jasa yang dimiliki di era pandemi. Bersinergi dengan influencer dan selebgram dalam menyampaikan nilai nilai dan keunggulan produk jas Industri wisata

4. Customer Relationships, media official yang lebih interaktif dengan masyarakat luas dengan cara membuat membership, diskon di eventevent tertentu untuk member, memiliki Focus Group Discussion yang dikelola dan diperhatikan dengan baik, membuat Maskot setiap semester.

5. Revenue Streams, menyusun kembali model sistem bagi hasil dan gaji yang lebih menguntungkan dari setiap item produk dan jasa. 
Membuat daftar produk dan jasa layanan yang priotitas ditingkatkan karena memiliki potensi laba yang besar

6. Key Resources, membentuk komunitas milineal asli Pujon Kidul, menggandeng organisasi kemasyarakat seperti PKK dalam mendukung pemasaran dan mempengaruhi kolega untuk berkunjung ke Industri wisata. Banyak potensi di masyarakat yang perlu diberdayakan melalui jaringan yang kuat maka akan berdampak secara signifikan.

7. Key Activities, penambahan protokol kesehatan di setiap aktivitas operasional, jaminan setiap staff dan crew selalu dalam kondisi sehat dan mematuhi protokol kesehatan, memberikan nutrisi tambahan berupa vitamin dan produk herbal bagi wisatawan yang menginap untuk menjaga imunitas dan kesehatan sekaligus mengenalkan potensi produk lokal. Semuanya dilakukan untuk memberikan pelayan optimal dan kepuasan pelanggan.

8. Key Partnerships, menjalin kerjasama yang baik dengan lembaga pendidikan PTN/PTS, CSR perusahaan profesional dan komunitas di masyarakat. Tri dharma perguruan tinggi menjadi salah satu alternatif kerjasama dalam waktu dekat. CSR perusahaan tentang pemberdayaan ekonomi mikro masyarakat perlu diakses.

9. Cost Structure, melakukan efisiensi anggaran dengan mengurangi pemborosan biaya operasional, membuat alternatif energi potensial yang ramah lingkungan khususnya dalam mensubstitusi sumber energi listrik.

\begin{tabular}{|c|c|c|c|c|}
\hline $\begin{array}{l}\text { Per } \\
\text { Des } \\
\text { Dire } \\
\text { BU } \\
\text { Dire } \\
\text { Sav } \\
\text { Per } \\
\text { pel } \\
\text { UM }\end{array}$ & $\begin{array}{l}\text { Key } \\
\text { Activities } \\
\text { Pemasaran } \\
\text { (offline/online) } \\
\text { Layanan } \\
\text { Edukasi dan } \\
\text { penginapan } \\
\text { Meningkatkan } \\
\text { kepuasan } \\
\text { dengan } \\
\text { penerapan } \\
\text { kesehatan, } \\
\text { Pemberian } \\
\text { Vitaman dan } \\
\text { Nutrisi Produk } \\
\text { Herbal } \\
\text { Key } \\
\text { Resources } \\
\text { SDM } \\
\text { masyarakat, }\end{array}$ & $\begin{array}{l}\text { Value } \\
\text { Propositions } \\
\text { lahan, } \\
\text { masakan dan } \\
\text { produk khas } \\
\text { asli } \\
\text { masyarakat } \\
\text { Desa Pujon } \\
\text { Alami dan } \\
\text { suasana } \\
\text { pegunungan } \\
\text { Jaminan } \\
\text { layanan } \\
\text { kesehatan, } \\
\text { keamanan }\end{array}$ & $\begin{array}{l}\text { Customer } \\
\text { Relationships } \\
\text { Hubungan } \\
\text { yang baik } \\
\text { Diskon dan } \\
\text { membership, } \\
\text { FGD, Maskot }\end{array}$ & $\begin{array}{l}\text { Customer } \\
\text { Segments } \\
\text { Masyarakat } \\
\text { Malang } \\
\text { Raya, Jawa } \\
\text { Timur dan } \\
\text { Masyarakat } \\
\text { Indonesia }\end{array}$ \\
\hline
\end{tabular}




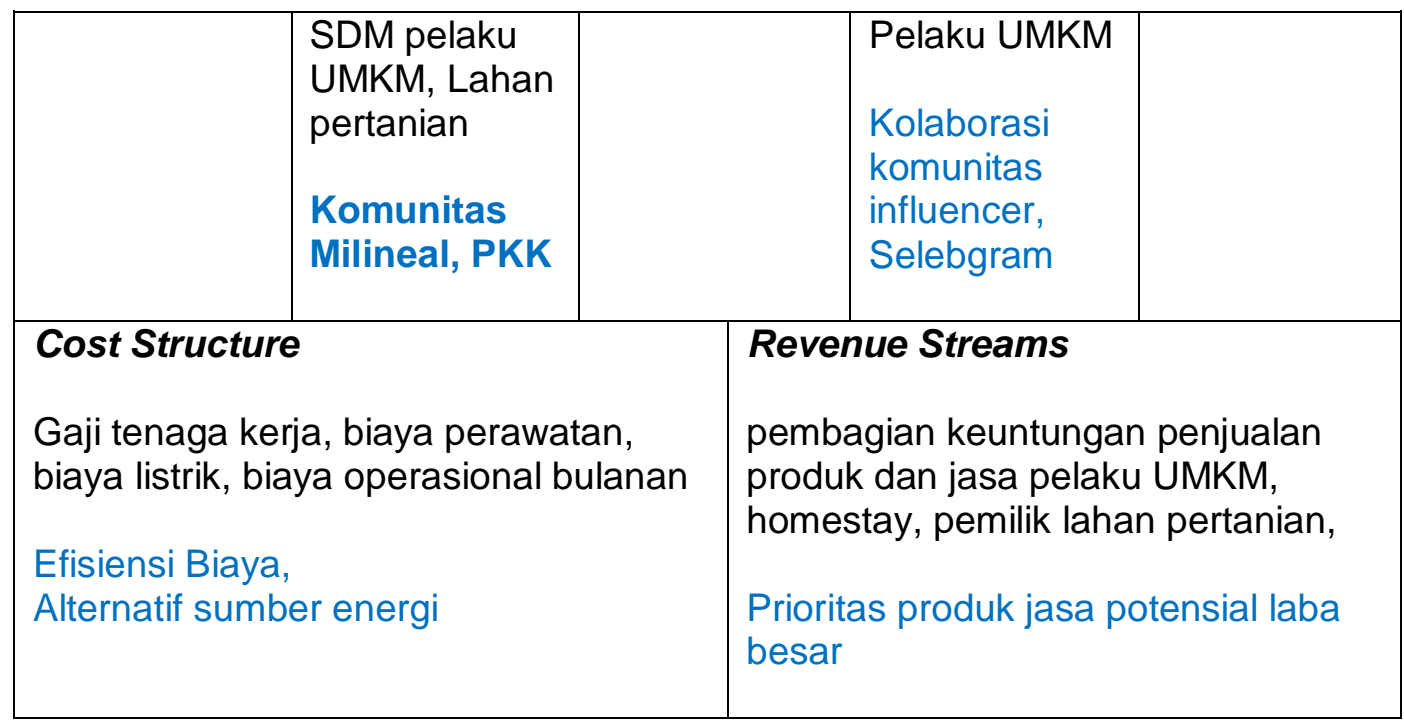

\section{Gambar 3. Perbaikan Bisnis Model Canvas}

Langkah langkah dalam kerangka kerja Perbaikan Bisnis Model Canvas bisa dilaksanakan dalam waktu dekat. Hal ini di dukung dengan beberapa kebijakan lembaga pendidikan perguruan tinggi yang selalu melaksanakan tri dharma bidang penelitian dan pengabdian kepada masyarakat. Secara teknis tinggal membuat MoU secara tertulis dan disepakati bersama. Setiap kegiatan industri wisata yang melibatkan masyarakat luas selalu mendapatkan perhatian oleh pemerintah daerah dan kementrian terkait sehingga membuka peluang untuk selalu dalam pembinaan pemerintah. Kolaborasi bersama akan memberikan dampak yang positif bagi keberlangsungan bisnis masyarakat di tengah new normal saat ini.

\section{KESIMPULAN}

Koordinat Industri Wisata Cafe Sawah Pujon Kidul untuk matriks IE ini adalah $(3,0 ; 2,8)$ strategi tumbuh dan membangun bisa melakukan pendekatan penetrasi pasar dan pengembangan produk. Penetrasi pasar dengan melakukan berbagai kegiatan promosi yang tepat dengan kondisi new normal. Pengembangan produk dengan melakukan kerjasama dan kolaborasi dengan semua lembaga potensial untuk merencanakan inovasi produk dan jasa terbaru. Pendekatan analisis Bisnis Model Canvas dapat diketahui terobosan yang bisa diterapkan saat ini di era new normal. Terobosan jangka pendek yang mendukung kelancaran bisnis Industri Wisata di era new normal.

Sedangkan saran dalam proses penelitian selanjutnya adalah mengukur tingkat kepuasan pengunjung dan kinerja pegawai sehingga sesuai dengan visi misi awal Industri wisata. Tingkat kepuasan pengunjung akan memberikan arahan pada proses pelayanan yang excellent dan kinerja pegawai akan menjadi informasi untuk menngetahui sumber daya manusia industri wisata sudah siap berstandard 
internasional. Saran untuk pengelola atau manajemen Industri Wisata membuat rencana kerja dan terobosan bisnis jangka pendek, jangka menengah dan jangka panjang.

\section{DAFTAR PUSTAKA}

Anonim. Undang Undang tentang Kepariwisataan, UU No. 10 Tahun 2009. Jakarta: Direktorat Jenderal Hukum dan HAM

Arifianto. E.Y., Choiri M. 2018. Pemanfaatan E-Commerce Dalam Pebelajaran Manajemen Usaha Kecil Dan Menengah. Jurnal Komunikasi Pendidikan 2 (1), 77-85.

Arifianto. E. Y., Prayogo, Setyowati, Nurul. 2019. Pengembangan Sumber Daya Manusia Dengan Pendekatan Konsep Manajemen Eduwisata Mikrohidro Dalam Mewujudkan Desa Mandiri. Prosiding Temu IImiah Nasional Balitbang Tahun 2019 "Percepatan Pengembangan Desa Mandiri".

David, Fred R. (2010). Manajemen Strategis Konsep. Jakarta : PT. Prenhallindo

David, Fred R. (2011). Strategic Management, Buku 1. Edisi 12. Jakarta: Salemba Empat

Hernadi, Matyani dan Patmawati. 2018. Pengembangan Ekonomi Masyarakat Melalui Pemberdayaan Usaha Mikro Kecil Dan Menengah (Studi Di Kelurahan Sumber Rejo Kecamatan Balikpapan Tengah Kota Balikpapan). Jurnal Abdi Masyarakat Ilmu Ekonomi Vol.01 No 01, Desember 2018.

Jhingan. M.L. 2014. Ekonomi Pembangunan Dan Perencanaan. Jakarta: Rajawali Pres.

Kuncoro, Mudrajad. 2018. Perencanaan Pembangunan Daerah Teori dan Aplikasi. Jakarta: Graha Media Pustaka Utama. 